\title{
Effect of sorghum replacement and probiotic on growth performance and feed utilization of the Nile Tilapia (Oreochromis niloticus).
}

\author{
Mohsen S. Hussein ${ }^{1}$; Abd El-monaam A. younes ${ }^{2}$ Mohamed W. Ali ${ }^{3}$ and \\ Abd El-Azem M. Abd El-azim ${ }^{3}$ \\ 1- Faculty of Agriculture, Al-Azhar University Cairo, Egypt. \\ 2- National Institute of Oceanography and fishers, Egypt. \\ 3- Central Lab for Aquaculture Research, in abo hammed Sharkia, Egypt.
}

\begin{abstract}
This study was conducted to evaluate the effect of replacing yellow corn (Zea maize) with sorghum (sorghum bicolor) on the growth performance and body composition of the Nile Tilapia. Sorghum was included into diets at four levels $(25 \%$, $50 \%, 75 \%$ and $100 \%$ ). The diets with zero sorghum level act as a control and response of fish fed on diets containing sorghum and additive Lacto cel-con supplementation (as probiotic) at a rate of $(0.3 \mathrm{~g} / \mathrm{kg}$ diet). All the diets were isonitrogenous and isoenergetic. The results after 16 week experimental period indicated that fish fed on the diets containing $75 \%$ sorghum + probiotic (T3) showed significantly better growth performance and feed utilization in terms final body weight, weight gain, mean daily gain, specific growth rate, feed conversion ratio, feed intake, protein efficiency ratio and net protein utilization than those fed on the control diet. The present study indicated that, the adverse effect of replacing yellow corn (Zea maize) with sorghum (sorghum bicolor) at $75 \%$ + probiotic is the best ratio on the growth performance and feed utilization as a fish meal in Tilapia diets.
\end{abstract}

Keywords: Replacement, growth performance, feed utilization, Nile tilapia, probiotic

\section{INTRODUCTION}

Total world tilapia production has increased annually from 2.5 million tons in 2004 to 3.5 million tons in 2011 and projected to reach 3.6 million tons in 2012 (Fitzsimmons et al., 2012) and the global sales have also increased from US\$ 1.7 billion to over US\$ 5.0 billion in 2010 . From the total world production of tilapias by weight and value, the Nile tilapia alone represents approximately $84 \%$. Its production has increased from around 200,000 tons in 1990 to about 2.8 million tons in 2010 (FAO 2009; Josupeit, 2010; Fitzsimmons et al., 2012). Chinese production of Nile tilapia is smaller (1.56 million tons) but still outstrips that of other nations, Egypt (0.84 tons), Indonesia ( 0.32 million tons), Thailand ( 0.21 million tons) and the Philippines (0.19 million tons) (FAO, 2011).

United States of America was the top producer of sorghum in 2009 , with a harvest of 9.7 million metric tons. The next four major producer of sorghum in decreasing quantities were India, Nigeria, Sudan and Ethiopia. The other major sorghum producing regions in the world by harvested quantities are Australia, Brazil, china, Burkina Faso, Argentina, Mali, Cameron, Egypt, Niger, United Republic of Tanzania, Chad, Mozambique, Venezuela and Ghana. The world harvested 55.6 million tons of sorghum in 2010 (FAO 2010)

Sorghum is a tropical cereal grass, has been cultivated in Africa for over 3000 years .Today sorghum is cultivated across the world in the warmer climatic areas in terms of volume it is the world's fifth most important cereal grain after wheat, maize 
,rice and barley .Sorghum is still largely a subsistence food crop ,but It is increasingly becoming the foundation for successful food and beverage industries .Finely Sorghum is similar in chemical composition to corn (Zea Maize) and wheat according to USDA (2008). Monosaccharaides are simple sugars such as glucose or fructose that are strung together to form the building blocks of polysaccharides such as starch (Albert's et al., 1998). The incorporation of carbohydrates is important in the fish diet so, protein and lipids are not catabolized for energy (NRC, 1993). Probiotic has several definitions in aquaculture. It has been described as a live microorganism food supplement which improves the microbial balance of the host intestinal flora (ZiaeiNejad et al., 2006). Its live microorganisms that improve disease resistance (Tacon, 2002); the use of microorganisms or their products (microbial cells element or cell free supernatant factors) in rearing and culture cages and ponds, as biological control or for their capacity to modify the bacterial composition of aquatic animal's intestine, water and sediment, or used with feed as health supplement or biological control. (Merrifield et al., 2010).

They are also refer to as bio-proteins containing living microbial cells that optimize the colonization and composition of the growth and gut micro flora in animals and stimulate digestive processes and immunity (Dhanaraj et al., 2010).

\section{Aim of the work}

This study was designed to evaluate the effect of different dietary sorghum levels supplemented with lactobacillus cells as inert probiotic on the growth performance, feed utilization, body composition, and some blood parameters of fingerlings mono-sex Nile tilapia (O. niloticus).

\section{MATERIALS AND METHODS}

Nile Tilapia (O. niloticus) fingerlings were from brood stock held at a private Tilapia hatchery at Fayoum Governorate Egypt. They were transferred to the National Institute of Oceanography and fisheries at Shakshouk Fayoum Governorate by using special fish transport car supply with pure oxygen cylinder. Fish was acclimatized to the experimental system condition for two weeks and fed on commercial diets containing (30\% crude protein) before starting the experiment. Experiment were started in ( $1^{\text {st }}$ April) and finished on July 2014 (120 day).

Total number of 600 monosex Nile tilapia (O. niloticus) fingerlings (40 fingerlings / each cage) were used with three replicates for each treatment. Fish were randomly distributed for all cages with amean initial weight $(2 \mathrm{~g})$ and were distributed at random ratio (control, sorghum and probiotics) experimental dietary.

\section{Experimental design}

Five experimental diets were formulated varying only in their dietary (Zea Maize) substitution with different levels of sorghum meal, where (control+ probiotic) considered to be the control without sorghum meal, then sorghum level partially and totally replaced (Zea Maize) as follows: T1 (25\% sorghum meal replacement); T2 (50 $\%$ sorghum meal replacement); T3 (75\% sorghum meal replacement) and T4 (100\% sorghum meal). Lacto bacillus cell was incorporated with $0.3 \%$ in (control+ probiotic, $\mathrm{T} 1, \mathrm{~T} 2, \mathrm{~T} 3$ and $\mathrm{T} 4)$

\section{Growth performance:}

Growth performance and feed parameters have been measured, body weight gain (WG), feed conversion ratio (FCR), feed intake per fish (FI), specific growth rate (SGR;\%), protein efficiency ratio (PER), condition factor $(\mathrm{K})$ and Protein productive value (PPV).These parameters were determined using by following methods: 
Body weight gain $\mathrm{WG}=(\mathrm{FW}-\mathrm{IW})$

FW = Final weight $(\mathrm{g})$

IW = Initial weight

Specific growth rate Pouomogne and Mbongblang, (1993)

Where: $\quad$ SGR $(\% /$ day $)=(\ln \mathrm{FW}-\ln \mathrm{IW}) / \mathrm{T} \times 100$

FW = final weight.

$\mathbf{I W}=$ initial weight.

$\mathbf{L n}=$ Natural logarithm

$\mathbf{T}=$ period (days)

Survival rate (SR \%) $=$ (final fish Number / initial Number of fish) X100

Condition factor (K): Estimated according to Bagemal (1978) as:

$\mathbf{K}=\mathbf{W} / \mathbf{L}^{3} \times 100$

Where: $\quad \mathbf{W}=$ fish weight $(\mathrm{g}) \quad \mathbf{L}=$ fish length $(\mathrm{cm})$

Feed utilization:

Feed conversion ratio by Tacon, (1987): $\mathbf{F C R}=$ Feed intake $(\mathrm{g}) /$ weight gain $(\mathrm{g})$

Protein efficiency ratio by Davies \& Morries (1997): PER (\%) = weight gain $(\mathrm{g}) /$ protein intake $(\mathrm{g}) \times 100$

Protein productive value by Marias and Kissil, (1979):

PPV (\%) = Retained protein $(\mathrm{g}) /$ protein intake (g) x 100

Statistical analysis:

The results were presented as means \pm SE of three replications. All data were subjected to one-way analysis of variance and tested. One way Analysis of Variance (ANOVA) was applied to test the effect of different sorghum levels and probiotic on various growth parameters, nutrient utilization, and blood parameters of experimental fish according to Snedecore \& Cochran (1987). Duncan Multiple Range test was used to detect the significant differences between the means of treatments Duncan (1955). All analysis were performed using SPSS version 20, (2014) SPSS Institute, Cary, NC, USA), SPS4S (2014).

\section{RESULTS}

\section{Physico chemical characteristics}

Results (Table 1) showed that the average values of water temperature in cages between were $28.3 \pm 0.2^{\circ} \mathrm{c}-28.5 \pm 0.3^{\circ} \mathrm{c}$. Average values of $\mathrm{PH}$ ranged between $7.5 \pm 0.1-7.7 \pm 0.2$ while salinity ranged between $4.1 \pm 1.1-4.2 \pm 1.1(\mathrm{~g} / \mathrm{l})$. Average values of Dissolved oxygen ranged between $7.1 \pm 0.1-7.2 \pm 0.4(\mathrm{mg} / \mathrm{l})^{3}$. While that of Ammonia ranged between $0.41 \pm 0.01-0.42 \pm 0.01\left(\mathrm{mg} / \mathrm{l}^{3}\right.$ and nitrate were between $0.004 \pm 0.01(\mathrm{mg} / \mathrm{l})^{3}$

Table 1: Average values of water quality parameters of all experimental ponds during the experimental period (16 weeks).

\begin{tabular}{|c|c|c|c|c|c|}
\hline \multirow[b]{2}{*}{ Parameters } & \multicolumn{5}{|c|}{ Sorghum level\% in (Table 1) } \\
\hline & Control & $\mathrm{T} 1$ & $\mathrm{~T} 2$ & T3 & T4 \\
\hline Temperature ${ }^{\circ} \mathrm{C}$ & $28.4 \pm 0.3$ & $28.5 \pm 0.3$ & $28.3 \pm 0.2$ & $28.4 \pm 0.3$ & $28.5 \pm 0.3$ \\
\hline Salinity $(\mathrm{g} / \mathrm{l})$ & $4.2 \pm 1.1$ & $4.1 \pm 1.2$ & $4.2 \pm 1.1$ & $4.1 \pm 1.2$ & $4.1 \pm 1.1$ \\
\hline $\mathrm{Ph}$ & $7.6 \pm 0.2$ & $7.6 \pm 0.3$ & $7.6 \pm 0.1$ & $7.7 \pm 0.2$ & $7.5 \pm 0.1$ \\
\hline Do .O. $(\mathrm{mg} / \mathrm{l})^{3}$ & $7.1 \pm 0.2$ & $7.1 \pm 0.1$ & $7.2 \pm 0.4$ & $7.1 \pm 0.2$ & $7.1 \pm 0.3$ \\
\hline $\mathrm{N}-\mathrm{NH}_{3}(\mathrm{mg} / \mathrm{l})^{3}$ & $0.42 \pm 0.01$ & $0.41 \pm 0.01$ & $0.42 \pm 0.01$ & $0.41 \pm 0.01$ & $0.41 \pm 0.01$ \\
\hline $\mathrm{N}-\mathrm{No}_{2}(\mathrm{mg} / \mathrm{l})^{3}$ & $0.004 \pm 0.01$ & $0.004 \pm 0.01$ & $0.004 \pm 0.01$ & $0.004 \pm 0.01$ & $0.004 \pm 0.01$ \\
\hline
\end{tabular}

\section{Growth performance}

As presented in (Table 2) growth performance mean values showed that averages of initial weights and lengths of the experiment start had ranged between $1.70 \pm 0.1$ - 
$2.15 \pm 0.059(\mathrm{~g})$ for weight and $2.00 \pm 0.11-2.50 \pm 0.13(\mathrm{~cm})$ in length, with insignificant differences among the experiments, indicating that the complete randomization of individual fish among the experimental trials at the start of the experiment and were homogenous. In the same table results showed that, at the end of the experimental period (16 weeks), the higher final weight was achieved in the experimental fish fed on diets which containing up to $75 \%$ sorghum meal with probiotic $80.70 \pm 0.7 \mathrm{~g}$ and had a significantly $(\mathrm{P}<0.05)$ higher total weight gain compared to the control diet than the rest of the experimental diets. The same trend was observed with weight gain recorded higher significant differences $(\mathrm{P}<0.05)$ in the fish fed on diet contain sorghum meal up to $(75 \%)$ with probiotic $78.55 \pm 0.65$ compared to other treatments. Also, the best values of final body length, specific growth rate and condition factor recorded with T3 (replacement $75 \%$ sorghum meal), but no significant differences between all treatments.

Table 2: Growth performance mean values (Mean \pm S.E. $n=20$ ) of tilapia fed on different experimental diets for 120 days.

\begin{tabular}{|c|c|c|c|c|c|}
\hline \multirow{2}{*}{ Parameters } & \multicolumn{5}{|c|}{ Experimental diets $\%$} \\
\hline & Control & $\mathrm{T} 1$ & $\mathrm{~T} 2$ & $\mathrm{~T} 3$ & $\mathrm{~T} 4$ \\
\hline Initial. fish weight $(\mathrm{g})$ & $1.70 \pm 0.1^{\mathrm{a}}$ & $1.95 \pm 0.05^{\mathrm{a}}$ & $2.02 \pm 0.08^{\mathrm{a}}$ & $2.15 \pm 0.05^{\mathrm{a}}$ & $1.99 \pm 0.1^{\mathrm{a}}$ \\
\hline Final fish weight (g) & $59.75 \pm 0.45^{\mathrm{e}}$ & $63.00 \pm 0.50^{d}$ & $66.40 \pm 0.1^{\mathrm{c}}$ & $80.70 \pm 0.7^{\mathrm{a}}$ & $70.60^{b} \pm 0.6^{b}$ \\
\hline Initial. fish length(cm) & $2.00 \pm 0.11^{\mathrm{a}}$ & $2.50 \pm 0.12^{\mathrm{a}}$ & $2.50 \pm 0.12^{\mathrm{a}}$ & $2.50 \pm 0.13^{\mathrm{a}}$ & $2.50 \pm 0.10^{\mathrm{a}}$ \\
\hline Final fish length (cm) & $16.30 \pm 0.81^{\mathrm{a}}$ & $16.54 \pm 0.67^{\mathrm{a}}$ & $16.60 \pm 0.60^{a}$ & $16.95 \pm 0.11^{\mathrm{a}}$ & $17.00 \pm 0.15^{\mathrm{a}}$ \\
\hline weight gain $(\mathrm{g})$ & $58.05 \pm 0.55^{\mathrm{e}}$ & $61.05 \pm 0.44^{\mathrm{d}}$ & $64.39 \pm 0.1^{\mathrm{c}}$ & $78.55 \pm 0.65^{\mathrm{a}}$ & $68.61 \pm 0.61^{b}$ \\
\hline Av. daily gain(g) & $0.49 \pm 0.05^{\mathrm{e}}$ & $0.51 \pm 0.05^{\mathrm{d}}$ & $0.53 \pm 0.05^{\mathrm{c}}$ & $0.66 \pm 0.05^{\mathrm{a}}$ & $0.57 \pm 0.05^{b}$ \\
\hline SGR ( \%/ day ) & $1.29 \pm 0.2^{\mathrm{a}}$ & $1.26 \pm 0.05^{\mathrm{a}}$ & $1.27 \pm 0.01^{\mathrm{a}}$ & $1.31 \pm 0.0^{\mathrm{a}}$ & $1.29 \pm 0.05^{\mathrm{a}}$ \\
\hline Condition factor(K) & $1.40 \pm 0.22^{\mathrm{a}}$ & $1.40 \pm 0.16^{\mathrm{a}}$ & $1.46 \pm 0.15^{\mathrm{a}}$ & $1.65 \pm 0.2^{\mathrm{a}}$ & $1.44 \pm 0.4^{\mathrm{a}}$ \\
\hline Survival ratio (SR \%) & $100 \%$ & $100 \%$ & $100 \%$ & $100 \%$ & $100 \%$ \\
\hline
\end{tabular}

As presented in (Table 3 ) feed utilization mean values showed that average amount of feed consumed were found to be $122.75 \pm 3.14,127.24 \pm 3.36,131.57 \pm 1.57$, $135.45 \pm 2.77$ and $127.75 \pm 5.38 \mathrm{~g}$ for fish feed control ,T1, T2, T3 and T4 respectively, which indicates light increases in feed consumption in fish feed T3 compared to other diets. The highest average value of (PER) 2.30土.005 was recorded by T3 group, followed with significance decreasing order by control, T1, T2, T3 and T4 groups respectively. Concerning the NPU\% values were $30.91 \pm 1.54,33.47 \pm 1.33$, $29.24 \pm 1.21,31.44 \pm 1.61$ and $32.37 \pm 1.45$ in the control feed group T1, T2, T3 and T4. Treatments $\mathrm{T} 1$ and $\mathrm{T} 4$ recorded the highest values comparing to other tested group.

Feed conversion ratio values $2.12 \pm 0.03,2.08 \pm 0.04,2.04 \pm 0.02,1.72 \pm 0.02$ and $1.86 \pm 0.06$ were recorded by control $\mathrm{T} 1, \mathrm{~T} 2, \mathrm{~T} 3$ and $\mathrm{T} 4$ respectively, with significance difference. The highest FCR value $(1.72 \pm 0.02)$ was recorded by T3 group compered to control, T1, T2 and T4 groups. Average feed efficiency (FE) was recorded this values $(0.47 \pm 0.005,0.48 \pm 0.005,0.49 \pm 0.005,0.58 \pm 0.005$ and $0.53 \pm 0.02)$ in control group, T1, T2, T3 and T4 respectively, and the highest value was recorded by T3 compared all tested diets. Average daily feed intakes in experimental diets were $(1.03 \pm 0.02,1.06 \pm 0.03,1.10 \pm 0.01,1.13 \pm 0.02$ and $1.07 \pm 0.04)$ in control group, T1, T2, $\mathrm{T} 3$ and $\mathrm{T} 4$ respectively; the highest value $(1.13 \pm 0.02)$ was recorded by $\mathrm{T} 3$ compared to all experimental diets. 
Table 3: Feed utilization mean values (Mean \pm S.E. $n=20$ ) of Nile tilapia

\begin{tabular}{|l|c|c|c|c|c|}
\hline \multirow{2}{*}{ Parameters } & \multicolumn{5}{|c|}{ Experimental diets $\%$} \\
\cline { 2 - 6 } & Control & T1 & T2 & T3 & T4 \\
\hline Feed intake (g/fish) (FI) & $122.95 \pm 3.14^{\mathrm{c}}$ & $127.24 \pm 3.36^{\mathrm{b}}$ & $131.57 \pm 1.57^{\mathrm{ab}}$ & $135.45 \pm 2.77^{\mathrm{a}}$ & $127.75 \pm 5.38^{\mathrm{a}}$ \\
\hline Daily Feed intake (D F I) & $1.03 \pm .02^{\mathrm{a}}$ & $1.06 \pm .03^{\mathrm{a}}$ & $1.10 \pm .01^{\mathrm{a}}$ & $1.13 \pm .02^{\mathrm{a}}$ & $1.07 \pm .04^{\mathrm{a}}$ \\
\hline Feed conversion ratio(FCR) & $2.12 \pm .03^{\mathrm{b}}$ & $2.08 \pm .04^{\mathrm{b}}$ & $2.04 \pm .02^{\mathrm{b}}$ & $1.72 \pm .02^{\mathrm{a}}$ & $1.86 \pm .06^{\mathrm{a}}$ \\
\hline Feed efficiency (FE) & $0.47 \pm .005^{\mathrm{c}}$ & $0.48 \pm .005^{\mathrm{c}}$ & $0.49 \pm .005^{\mathrm{c}}$ & $0.58 \pm .005^{\mathrm{a}}$ & $0.53 \pm .02^{\mathrm{b}}$ \\
\hline protein efficiency ratio (PER) & $1.75 \pm .16^{\mathrm{b}}$ & $1.91 \pm .04^{\mathrm{b}}$ & $1.95 \pm .02^{\mathrm{b}}$ & $2.30 \pm .005^{\mathrm{a}}$ & $2.15 \pm .07^{\mathrm{a}}$ \\
\hline $\begin{array}{l}\text { Net protein utilization (NPU) } \\
\%\end{array}$ & $30.91 \pm 1.54^{\mathrm{b}}$ & $33,47 \pm 1.33^{\mathrm{a}}$ & $29,24 \pm 1.21^{\mathrm{b}}$ & $31,44 \pm 1.61^{\mathrm{a}}$ & $32,37 \pm 1.45^{\mathrm{a}}$ \\
\hline
\end{tabular}

Proximate composition of whole fish body values for fish fed on experimental diets are given in Table (4). At the end of the experiment, no significant differences were detected in the whole body dry matter $(27.14-28.01 \%)$, protein $(15.30-$ $15.65)$, lipid $(5.20-6.57)$, ash $(5.97-6.90)$ contents of fish fed with the different experimental diets $(\mathrm{P}>0.05)$.

Table 4: Carcass analysis (Mean \pm S. E. $n=20$ ) of tilapia fed on the experimental diets ( $\% \mathrm{w} / \mathrm{w}$ basis).

\begin{tabular}{|l|c|c|c|c|c|}
\hline \multirow{2}{*}{ Chemical analysis } & \multicolumn{5}{|c|}{ Experimental diets\% } \\
\cline { 2 - 6 } & control & $\mathrm{T} 1$ & $\mathrm{~T} 2$ & $\mathrm{~T} 3$ & $\mathrm{~T} 4$ \\
\hline Dry matter (DM) & $27.40 \pm 0.15^{\mathrm{a}}$ & $27.14 \pm 0.20^{\mathrm{a}}$ & $27.45^{\mathrm{b}} \pm 0.15^{\mathrm{a}}$ & $28.01 \pm 0.25^{\mathrm{a}}$ & $27.99 \pm 0.25^{\mathrm{a}}$ \\
\hline Crude protein (CP) & $15.30 \pm 0.05^{\mathrm{a}}$ & $15.55 \pm 0.01^{\mathrm{a}}$ & $15.63 \pm 0.05^{\mathrm{a}}$ & $15.65 \pm 0.01^{\mathrm{a}}$ & $15.42 \pm 0.04^{\mathrm{a}}$ \\
\hline Ether extract (EE) & $5.20 \pm 0.05^{\mathrm{a}}$ & $5.32 \pm 0.10^{\mathrm{b}}$ & $5.85 \pm 0.15^{\mathrm{ab}}$ & $6.20 \pm 0.15^{\mathrm{ab}}$ & $6.57 \pm 0.10^{\mathrm{a}}$ \\
\hline Ash & $6.90 \pm 0.03^{\mathrm{a}}$ & $6.27 \pm 0.02^{\mathrm{a}}$ & $5.97 \pm 0.05^{\mathrm{a}}$ & $6.16 \pm 0.02^{\mathrm{a}}$ & $6.00 \pm 0.02^{\mathrm{a}}$ \\
\hline
\end{tabular}

Results in Table (5) showed that, the highest average values of white blood cells (WBCs) were significantly increased $(\mathrm{p}<0.05)$ with the increasing replacement at $100 \%$ sorghum meal and the lowest value has been shown in diets containing of $25 \%$ sorghum meal. Average values of red blood cells (RBCs) had no significant differences between all treatments. In the same trend Lymphocyte, hemoglobin and hematocrit. The highest values of red blood cells and hematocrit have been shown in $\mathrm{T} 3(75 \%+$ probiotic), while the highest values were in the control group.

Table 5: Blood parameters mean values (Mean \pm S.E. $n=20$ ) of tilapia fed on different experimental diets for 120 days.

\begin{tabular}{|l|c|c|c|c|c|}
\hline \multirow{2}{*}{ Parameters } & \multicolumn{5}{|c|}{ Experimental diets\% } \\
\cline { 2 - 6 } & Control & T1 & T2 & T3 & T4 \\
\hline WBCs & $73.50 \pm 0.96^{\mathrm{b}}$ & $72.30 \pm 0.92^{\mathrm{b}}$ & $75.56 \pm 0.78^{\mathrm{a}}$ & $77.76 \pm 0.74^{\mathrm{a}}$ & $78.15 \pm 0.73^{\mathrm{a}}$ \\
\hline RBCs & $2.49 \pm 0.10^{\mathrm{a}}$ & $2.32 \pm 0.06^{\mathrm{a}}$ & $2.29 \pm 0.06^{\mathrm{a}}$ & $2.27 \pm 0.06^{\mathrm{a}}$ & $2.25 \pm 0.06^{\mathrm{a}}$ \\
\hline Lymphocyte & $91.49 \pm 1.50^{\mathrm{a}}$ & $91.00 \pm 1.47^{\mathrm{a}}$ & $92.63 \pm 1.54^{\mathrm{a}}$ & $93.63 \pm 1.54^{\mathrm{a}}$ & $91.63 \pm 1.54^{\mathrm{a}}$ \\
\hline Hemoglobin & $9.60 \pm 0.20^{\mathrm{a}}$ & $9.10 \pm 0.25^{\mathrm{a}}$ & $9.10 \pm 0.25^{\mathrm{a}}$ & $9.00 \pm 0.25^{\mathrm{a}}$ & $9.20 \pm 0.25^{\mathrm{a}}$ \\
\hline Hematocrit & $34.20 \pm 0.78^{\mathrm{a}}$ & $34.70 \pm 0.79^{\mathrm{a}}$ & $34.40 \pm 0.33^{\mathrm{a}}$ & $34.70 \pm 0.33^{\mathrm{a}}$ & $34.70 \pm 0.33^{\mathrm{a}}$ \\
\hline
\end{tabular}




\section{Economic evaluation}

The economical evaluation of the experimental diet contained different sorghum levels to replace $25,50,75$, and $100 \%$ adding probiotic are shown in Table (6). The lowest cost to produce one $\mathrm{Kg}$ of the experimental diet compared with the cost of control diet was obtained when diet contained 75\% sorghum; it was 6.58 LE. The reduction in feed cost compared with control diet was 8.69 LE. It's the total cost of diets to produce one $\mathrm{Kg}$ fish gain of treatment containing $75 \%$ sorghum + probiotic and control respectively.

Table 6: The economic study on sorghum and maize for commercial diets of fish.

\begin{tabular}{|l|c|c|c|c|c|c|}
\hline \multicolumn{1}{|c|}{ Treatment } & Control & T1 & T2 & T3 & T4 & DS100P \\
\hline Parameters & 4.1 & 3.95 & 3.9 & 3.83 & 3.81 & 3.81 \\
\hline Price/Kg feed P.T & 2120 & 2080 & 2040 & 1720 & 1860 & 1860 \\
\hline FCR intake of tone Biomass & 2.12 & 2.08 & 2.04 & 1.72 & 1.86 & 1.86 \\
\hline Total price feed per Ton biomass & 8692 & 8216 & 7956 & 6587 & 7086 & 7086 \\
\hline Economic efficiency (\%) & 100 & 95 & 91 & 69 & 88 & 122 \\
\hline
\end{tabular}

\section{DISCUSSION}

The results of the current study showed that based feed can be used up to $33 \%$ sorghum meal to replace $75 \%$ of Zea maize without exerting any deleterious effect on growth performance and feed efficiency of Tilapia fingerlings. This means reducing (Zea maize) by replacing with sorghum meal. Carbohydrates are metabolized by glycolysis or the pentose phosphate pathway, leading to generation of energy transfer molecules in fish (Polakof et al., 2012). Also, dietary carbohydrates could depress the increase rate of amino acid metabolism and utilization by gluconeogenic pathways in salmon fish (Sanchez-Muros et al., 1996). Overall, the different levels of wheat starch fed to (Arctic char) and tilapia resulted in variation in metabolic profiles. As presented in table 6, the growth performance parameters (final weight, daily gain, specific growth rate and condition factor) recorded an increase with T3, which incorporated $33 \%$ of sorghum meal to replacing $75 \%$ of maize meal. These results are agree with the results of certain fish species such as Tilapia, red tilapia, channel catfish, grass carp and sea bream possess the ability to utilize up to $40 \%$ of dietary (maize or sorghum) starch sources (Lin, 1991; Luquet, 1991; Satoh, 1991; Al-Ogaily et al., 1996; Wang, 2005 ;Solomon et al.,2007). On the other hand, recording a high inclusion level of low tannin, sorghum $0.4 \%$ tannin up to ( $44 \%$ of diet) can be used in feeding of Nile tilapia. These data suggest a great potential for sorghum to replace maize in feeding of tilapia without compromising growth or protein utilization. Adequate feed intake is a precondition to guarantee a precise nutritional evaluation of fish feeds. The fish received T3 (75\% + Probiotic) which contains lacto-bacillus cells showed an increased in feed intake and feed efficiency. Feed intake reduction has been observed when the diet including unpalatable ingredients. This agrees with the previous results of sea bream reported by (Kissil et al; 2000). This may be related to the presence of detractive compounds in plant derived ingredients.

As can be seen in Table 3, a decrease in feed conversion ratio and increase in protein utilization (PER and NPU) with diet T3 $(75 \%+$ P), reflected efficient feed 
utilization by Tilapia fingerlings. The present results were also comparable with the previous values registered with Nile and red tilapia by Wang;(2005).

The blood physiology of fingerlings tilapia from (Hematocrit, Hemoglobin, Red blood cell and Lymphocyte) was investigated in the present study with respect to the effects of sorghum inclusion levels. The results obtained, indicated that the levels of blood parameters did not affect by sorghum inclusion and were within the normal values recorded in this species (Chang et al.,1999). However, the significance differences and the high levels of $\mathrm{RBC}$ recorded with the use of lactobacillus cells in different groups may be due to the immunity effects of these probiotics. The knowledge of the body composition of fish and factors affecting it allows the assessment of fish health, determination of efficiency of transfer of nutrients from the food to the fish, make it possible to predictably modify carcass composition (AlOgaily et al., 1996). The result of carcass composition in this study was in accordance with the growth performance results. The fish fed on the sorghum based diet was not statistically significant differences $(\mathrm{P}>0.05)$ comparing to the other fish fed on Zea maize. This observation agrees with the reported results of Al-Ogaily et al., (1996). The present results of whole body composition between different treatments were not affected by sorghum inclusion levels. Such values are within the range of those previously recorded in O. niloticus by Anderson et al. (1984).

\section{CONCLUSION}

Replacement of the dietary Zea maize by sorghum meal up to $75 \%$ (33\% inclusion level in the diet T3 (75+ Probiotic) did not adversely affect growth performance, nutrient utilization, some hematological parameters and proximate composition of the Nile tilapia fingerlings. The results confirm the feasibility of using sorghum meal in the feed formulation as alternative and cheap carbohydrate source to Zea maize in feeding Tilapia, due to less cost and palatability of this species. Further studies on sorghum digestibility could still be needed to help selecting the adequate inclusion and combination with other cereals crops for obtaining least cost diet formulation.

\section{REFERENCES}

Al Ogaily, S.M.; N .A and Ali, A. (1996). Effect of feeding different grain sources on the growth performance and body composition of Tilapia (Oreochromis niloticus (L).Aquaculture Res., 27:523-529

Alberts, B.; Bray, D.; Johnson, A.; Lewis, J.; Raff, M.; Roberts, K. and Walter, P. (1998). Essential Cell Biology: An Introduction to the Molecular Biology of the Cell. Garland Publishing, New York, NY, 593 pp.

Anderson, J.; Jackson, A.J.; Matty, A.J. and Capper, B.S. (1984). Effects of dietary carbohydrate and fiber on the tilapia Oreochromis niloticus (Linn.). Aquaculture, 37 (4):303-314.

Chang, C.I. and Liu, W.Y (1999). An evaluation of two probiotic bacterial strains, Enterococcus faecium SF68 and Bacillus toyoi, for reducing edwardsiellosis in cultured European eel, Anguilla anguilla L. J. Fish Dis., 25:311-5.

Chang, C.I. Liu, W.Y (2002). An evaluation of two probiotic bacterial strains, Enterococcus faecium SF68 and Bacillus toyoi, for reducing edwardsiellosis in cultured European eel, Anguilla anguilla L. J. Fish Dis., 25:311-315. 
Davies, S. J. and Morris, P. C. (1997). Influence of multiple amino acid supplementation on the performance of rainbow trout, Oncorhynchus mykiss (walbaum), fed soya based diets. Aqua Res., 28: 65- 74.

Dhanaraj, A.; Haniffa, M. A.; Arun singh, S. V.; Jesu Arockiaraj, A.; Muthu Ramakhrishanan, C.; Seetharaman, S. and Arthimanju, R. (2010). Effects of probiotics on growth performance of Koi carp (Cyprinus carpio). J. Appl. Aquacul., 22:202-209.

FAO (Food and Agriculture Organization) (2009). FAO Yearbook. Fishery and aquaculture statistics.

FAO (Food and Agriculture Organization) (2010). FAO Yearbook. Fishery and aquaculture statistics.

FAO (2011). Food and Agriculture Organization of the United Nations: The State of World Fisheries and Aquaculture, Rome.

Fitzsimmons, K.; Ramotar, M. R. and Loc, P. T. (2012). Global production and market situation in Tilapia continues to climb the charts. Aquaculture, 2012 Meeting Abstract.

Josupeit, H. (2010). World supply and demand of tilapia. FAO, Rome. Online:http://www.globefish.org/world-supply-and-demand-of-tilapia.html.

Kissil, G. W.; lupatsch; Higgs, D. A. and Hardy, R. W.(2000).Dietarysubstitution of soy and rapeseed protein concentrates for fish meal, and their effects on growth and nutrient utilization in gilthead sea bream (sparus aurata). Aquaculture Research, 31:595-601.

Lin, D. (1991). Grass carp, Ctenopharyngodon idellu. In: R.P. Wilson (Editor), Handbook of Nutrient Requirements of Finfish, CRC Press, Boca Raton, FL, pp. 89-96.

Luquet, P. (1991). Tilapia, Oreochromis spp. In: R.P. Wilson (Editor), Handbook of nutrient requirements of Finfish, CRC Press, Boca Raton, FL, pp. 169-179.

Merrifield, D.L.; Dimitroglou, A.; Foey, A.; Davies, S.J; Baker, R.M.T.; Bogwald, J.; Castex, M. and Ringo, E. (2010). The current status and future focus of probiotic and prebiotic applications for salmonids. Aquaculture, 302:1-18.

NRC (1993). National Research Council. Nutrient requirements of fish: Digestibility and absorption. National Academy Press, Washington, D. C. pp 43-44.

Polakof, S.; Panserat, S.; Soengas, J.L. and Moon, T.W. (2012). Glucose metabolism in fish: a review. Journal of Comparative Physiology B-Biochemical Systemic and Environmental Physiology 182(8): 1015-45.

Ringø, E.; Oldsen, R.E.; Gifstad, T.O.; Dalmo, R.A. and Amlund, H. (2010). Prebiotics in aquaculture: review. Aquaculture Nutr., 16: 117-136.

Sanchez-Muros, M.J.; Garcia-Rejon, L.; Lupianez, J.A. and De La Higuera, M. (1996). Long-term nutritional effects on the primary liver and kidney metabolism in rainbow trout (Oncorhynchus mykiss). II. Adaptive response of glucose 6-phosphate dehydrogenase activity to high-carbohydrate/low-protein and high-fat/on-carbohydrate diets. Aquaculture Nutrition 2(4), 193-200.

Satoh, S. (1991). Common carp, Cyprinus carpio. In: R.P. Wilson (Editor), Handbook of nutrient requirements of Finfish, CRC Press, Boca Raton, FL, pp. 55-67. 54

Solomon, S. G.; Tiamiyu, L. O. and Agaba, U. J. (2007).Effect of feeding different grain sources on the growth performance and body composition of Tilapia (Orechromis niloticus) fingerlings fed in outdoor haps Pakistan journal of nutrition., 6(3):271-275 Supplementation on the performance of rainbow trout, Oncorhynchus mykiss (walbaum), fed soya based diets. Aqua Res., 28: 65- 74. 
Tacon, A.G.J. (2002). Thematic review of feeds and feed management practices in shrimp aquaculture. Report prepared under the World Bank, NACA, WWF and FAO consortium program on shrimp farming and the environment. Work in Progress for Public Discussion. Published by the Consortium, pp. 69

Wang, Y.B.; Xu, Z.R. and Xia, M.S. (2005). The effectiveness of commercial probiotics in Northern White Shrimp (Penaeus vannamei L.) ponds. Fish. Sci., 71: 1034-1039.

Ziaei-Nejad, S.; Rezaei, M.H.; Takami, G.A.; Lovett, D.L.; Ali-Reza, Mirvaghefi, A.R. and Shakouri, M. (2006). The effect of Bacillus spp. bacteria used as probiotics on digestive enzyme activity, survival and growth in the Indian white shrimp Fenneropenaeus indicus. Aquaculture, 252:516-24. Northern White Shrimp (Penaeus vannamei L.) ponds.Fish. Sci., 71: 1034-1039.

\footnotetext{
ARABIC SUMMARY

"تأثير استبدال السورجم والبروبيوتك على معدلات النمو وكفاءة الغذاء فى اسماك البلطي النيلي

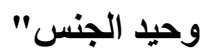

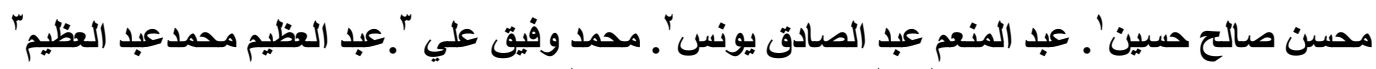

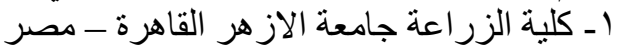

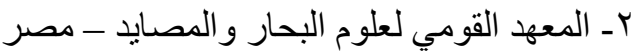

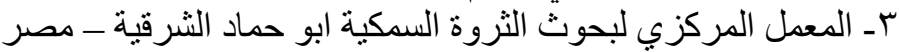

هذه الدراسة اجريت لتقيم نأثثر احلال الذرة الصفراء بالذرة الرفيعة (السورجم) علي معدلات النمو

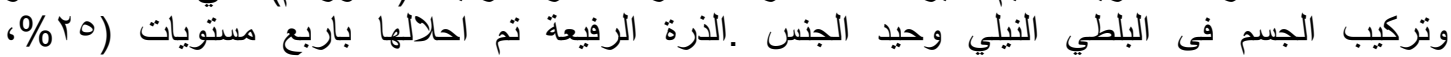

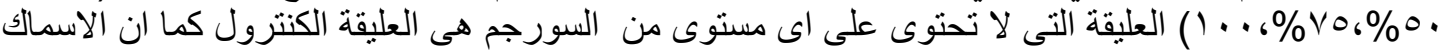

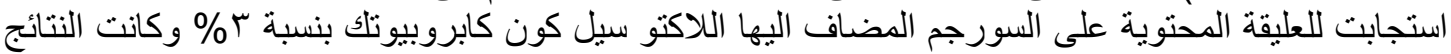

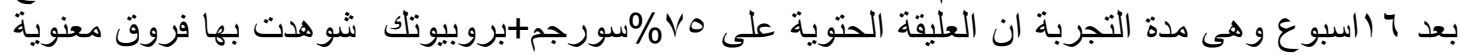

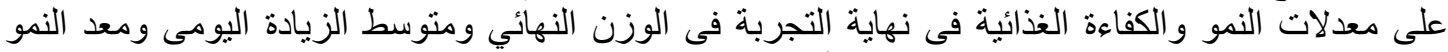

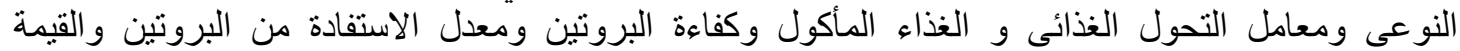
الانتاجية للبروتين اكثر من باقي العلائق و عليقة الكنترول.

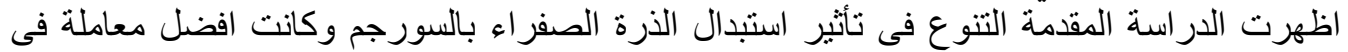

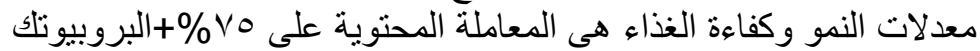

